\title{
EVALUATION OF PORE SIZES IN WELDED JOINTS MADE IN VARIOUS CONSTRUCTIONAL MATERIALS ON THE BASIS OF PENETRANT TESTING BY COLOUR METHOD
}

\begin{abstract}
It has been compared the dimensions of indications obtained in colour liquid-penetrant inspection. The indications arose from simulated pores drilled in test elements. The series of penetrant tests included different structural materials. On the basis of test results it has been ascertained the possibility of evaluation of the pores depth as well as it has been determined recommended development times for different constructional materials.

Keywords: imperfection, defect, penetrant testing, surface pores
\end{abstract}

\section{Introduction}

In most cases welded joints are characterized by deviations from the state considered to be ideal one. The deviations are called welding imperfections. Their presence decreases usually the operating properties of the joints [1-4]. It results from the above that the kind, size and number of imperfections in the joint should be limited to the minimum which provides safe and failure-free operation of the welded construction during the whole time of its use. The achievement of this purpose is possible by application of many different methods of non-destructive testing, among other things. To the oldest methods, commonly used in industrial practice, belongs penetrant testing [5].

Penetrant testing allows to detect exclusively the imperfections getting out to the surface (outer ones) which are pores, among the others. The pores can achieve a considerable depth. This is an undesirable feature in the aspect of the operational life of the joint and its leak tightness. For that reason the possibility of evaluation of the pores depth is of great importance in practice because in many cases it makes easier to take the decision about permission of the construction under inspection to the use in accordance with its appropriation or about its repair.

The penetration method enables to visualize the surface imperfections in the form of the red (most often) or luminous indication, according to the testing technique (Fig. 1) [6,7].

The pores depth can be evaluated only on the basis of the measurement of indication dimensions because they are proportional to the cross-sectional area (and then to the diameter) of the imperfection and to its depth. For that reason it has been undertaken the investigations aimed at determination of the relationships between the size of penetration indications and the time of their development vs. discontinuity dimensions ( diameter and

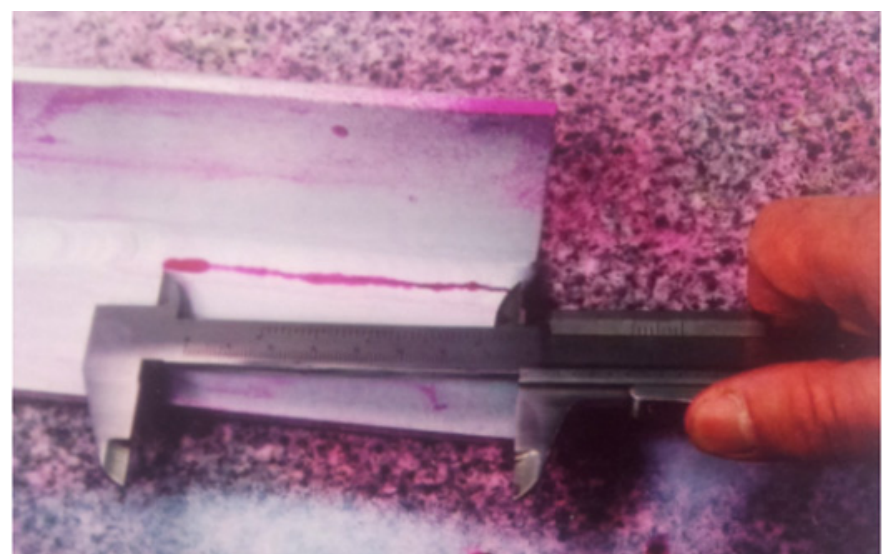

a)

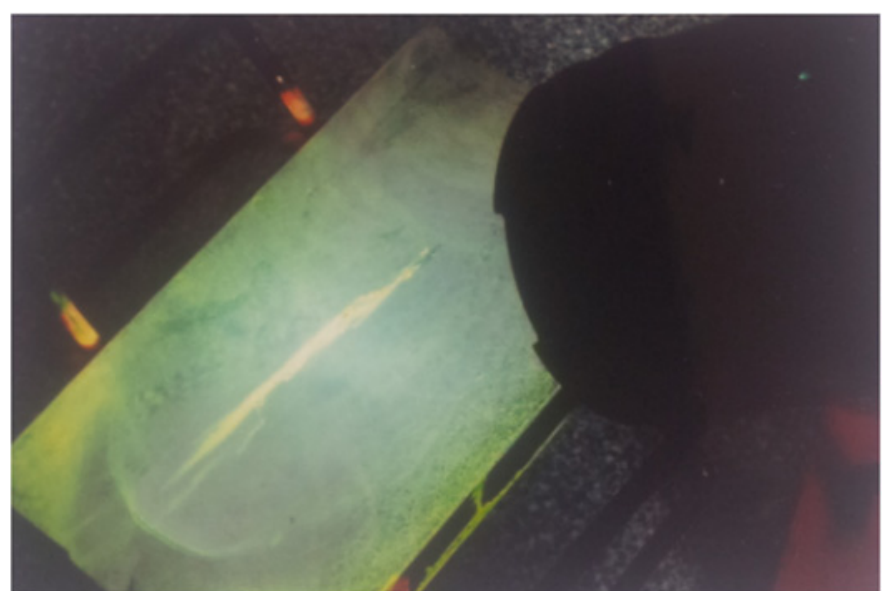

b)

Fig. 1. Examples of indications obtained during penetrant testing: a) with the use of colour technique (the surface under testing is observed in natural or artificial white light), b) with the use of fluorescent technique (the surface is observed in UV radiation)

\footnotetext{
* INSTITUTE OF WELDING, POLAND, 16-18 BŁ. CZESŁAWA STR., 44-100 GLIWICE, POLAND

\# Corresponding author: pawel.irek@is.gliwice.pl
} 
depth). The relationships will be useful in diagnostics of welded joints tested by colour penetration technique.

The tests were carried out on different structural materials [8-10]. This paper is the summary of fragmentary research works performed earlier. These tests are very important in mechanical engineering, especially for the wearing behavior of weld structures [11-12].

\section{Specimens for tests}

In order to determine the relationships enabling to evaluate the depth of pores detected by colour penetration technique it was used the simulation of these pores in the form of blind holes made in elements, $4 \mathrm{~mm}$ in thickness, of the following materials:

- $\quad$ S235 constructional carbon steel,

- AlMg5 aluminium alloy,

- $\quad \mathrm{X} 5 \mathrm{CrNi18-10}$ high alloy steel (Fig. 2).
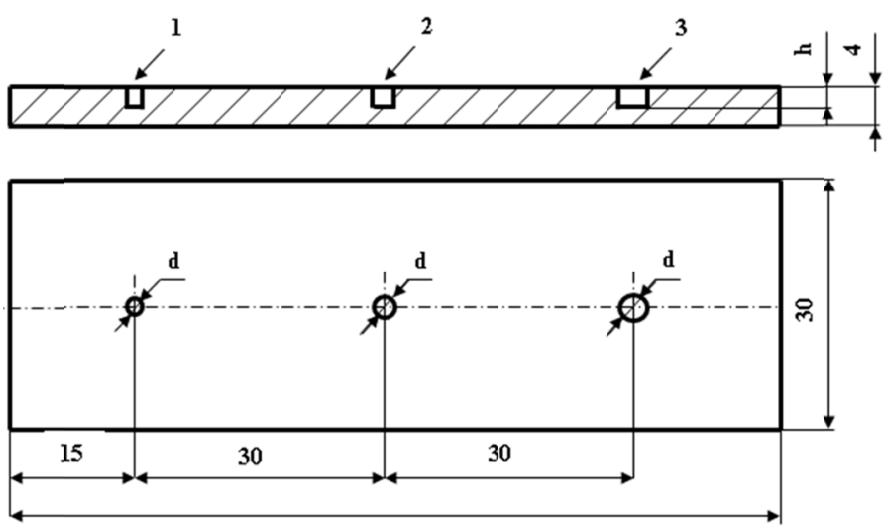

Fig. 2. Shape and dimensions of specimens made of different constructional materials, with holes simulating welding imperfections in the form of pores, for testing by colour penetration technique; 1, 2, 3 - designation of holes, $\mathrm{d}$ - hole diameter, $\mathrm{h}$ - hole depth

In order to optimize the penetrant testing process run and considering the operator's psychophysical abilities and the measurement accuracy of indications, in every specimen it was made only 3 holes. Nominal dimensions of the holes are set up in the Table 1.

After machining, the specimens were cleaned precisely by the removal of the post-machining remainder and degreasing of the surface to be tested. The degreasing was carried out in the ultrasonic washing stand using the extraction naphtha and solvent remover. Next, the specimens were dried by the moisture-free and oil-free compressed air stream. The temperature of the air stream was about $20^{\circ} \mathrm{C}$.

\section{Preparations, equipment and testing conditions}

For colour penetrant testing of specimens with simulated pores it was used the preparation set denoted by the IICe-2 symbol according to the EN ISO 3452-1, of the „Diffu - Therm”
TABLE 1

Designation of specimens for penetrant testing, holes in specimens and their nominal dimensions

\begin{tabular}{|c|c|c|c|c|}
\hline \multirow{2}{*}{$\begin{array}{l}\text { Ser. } \\
\text { No. }\end{array}$} & \multirow{2}{*}{$\begin{array}{l}\text { Designation } \\
\text { of specimen }\end{array}$} & \multirow{2}{*}{$\begin{array}{c}\text { Designation } \\
\text { of holes in the } \\
\text { specimen }\end{array}$} & \multicolumn{2}{|c|}{ Nominal dimensions of holes } \\
\hline & & & $\begin{array}{l}\text { diameter „d” } \\
{[\mathrm{mm}]}\end{array}$ & $\begin{array}{c}\text { depth „h” }{ }^{1)} \\
{[\mathrm{mm}]}\end{array}$ \\
\hline 1 & \multirow{3}{*}{ I } & 1 & 0,50 & \multirow{6}{*}{0,50} \\
\hline 2 & & 2 & 0,75 & \\
\hline 3 & & 3 & 1,00 & \\
\hline 4 & \multirow{3}{*}{ II } & 1 & 1,25 & \\
\hline 5 & & 2 & 1,50 & \\
\hline 6 & & 3 & 1,75 & \\
\hline 7 & \multirow{3}{*}{ III } & 1 & 0,50 & \multirow{6}{*}{0,75} \\
\hline 8 & & 2 & 0,75 & \\
\hline 9 & & 3 & 1,00 & \\
\hline 10 & \multirow{3}{*}{ IV } & 1 & 1,25 & \\
\hline 11 & & 2 & 1,50 & \\
\hline 12 & & 3 & 1,75 & \\
\hline 13 & \multirow{3}{*}{ V } & 1 & 0,50 & \multirow{6}{*}{1,00} \\
\hline 14 & & 2 & 0,75 & \\
\hline 15 & & 3 & 1,00 & \\
\hline 16 & \multirow{3}{*}{ VI } & 1 & 1,25 & \\
\hline 17 & & 2 & 1,50 & \\
\hline 18 & & 3 & 1,75 & \\
\hline 19 & \multirow{3}{*}{ VII } & 1 & 0,50 & \multirow{6}{*}{1,25} \\
\hline 20 & & 2 & 0,75 & \\
\hline 21 & & 3 & 1,00 & \\
\hline 22 & \multirow{3}{*}{ VIII } & 1 & 1,25 & \\
\hline 23 & & 2 & 1,50 & \\
\hline 24 & & 3 & 1,75 & \\
\hline 25 & \multirow{3}{*}{ IX } & 1 & 0,50 & \multirow{6}{*}{1,50} \\
\hline 26 & & 2 & 0,75 & \\
\hline 27 & & 3 & 1,00 & \\
\hline 28 & \multirow{3}{*}{$X$} & 1 & 1,25 & \\
\hline 29 & & 2 & 1,50 & \\
\hline 30 & & 3 & 1,75 & \\
\hline 31 & \multirow{3}{*}{ XI } & 1 & 0,50 & \multirow{6}{*}{1,75} \\
\hline 32 & & 2 & 0,75 & \\
\hline 33 & & 3 & 1,00 & \\
\hline 34 & \multirow{3}{*}{ XII } & 1 & 1,25 & \\
\hline 35 & & 2 & 1,50 & \\
\hline 36 & & 3 & 1,75 & \\
\hline
\end{tabular}

1) In relation to discontinuities (welding imperfections) the term „height” should be applied, however, in the paper, the term „depth” was used with a view to make the content more comprehensible.

type, of the H. Klumpf Techn. Chemie KG D-45699 Herten manufacture (Fig. 3).

The preparations are characterized by the following data: penetrant - red colour, BDR-L type, series no. 2116 , date of filling: 09/2014; remover - BRE type, series no. 22 16, date of filling: 02/2014; developer-BEA type, series no. 2316 , date of filling: 06/2014, warranty - 2 years, lack of chlorine and sulphur compounds in their composition.

During tests it was used the following equipment: luxmeter of the LX 105 type, manufactured by LX Lutron company, thermometer/hygrometer, model: MODEL 303, slide caliper, 


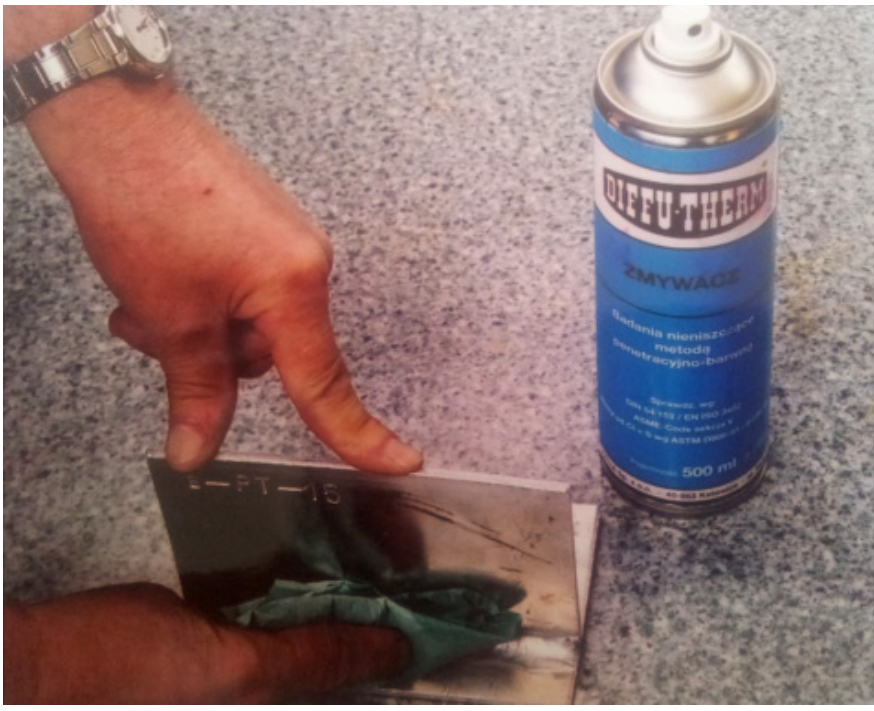

Fig. 3. Container with „Diffu - Therm” remover used for the removal of the excess of penetrant from the surface of the test fillet weld

exact to $0,02 \mathrm{~mm}$, workshop magnifying glass, magnification up to $4 \times$, non fraying woven fabric.

Penetrant testing of specimens with simulated pores was carried out under the following conditions: temperature of the surface under testing $-22^{\circ} \mathrm{C}$, surroundings humidity $-23 \%$, penetration time -15 minutes, development time -30 or 60 minutes, according to the test material, luminance of the surface under testing - $584 \mathrm{~lx}$, observation of indications - from the distance of 10-30 cm, observation angle - from 60 to $90^{\circ}$.

\section{Tests and their results}

Penetrant testing of specimens with simulated pores was carried out in accordance with PN-EN ISO 3452-1 specifications. The time of development for unalloyed construction steel and

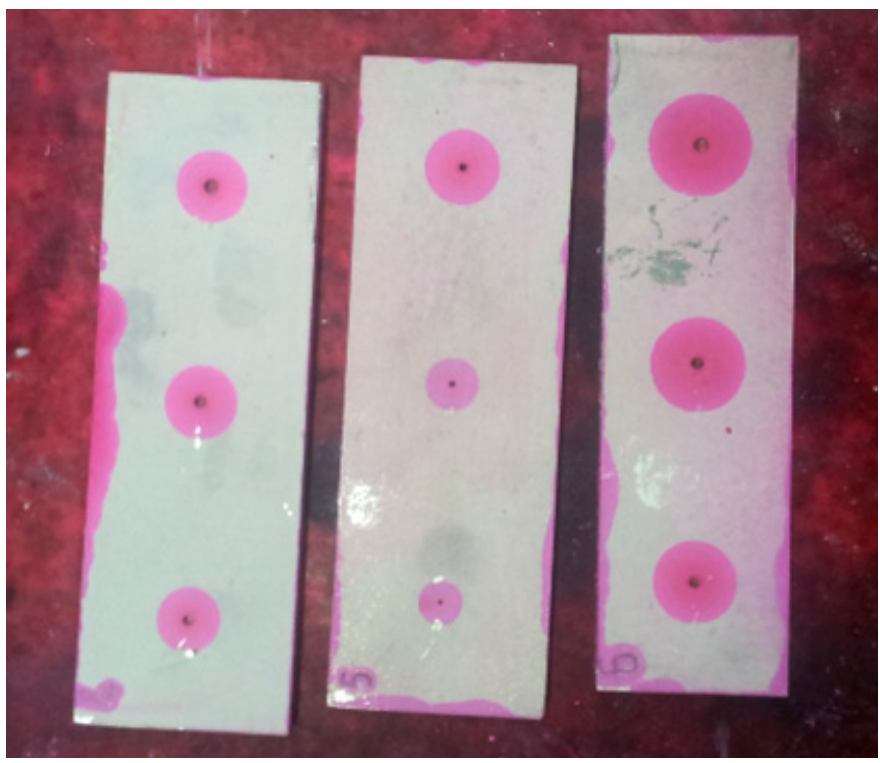

Fig. 4. Specimens made of aluminium alloy with developed indications from simulated pores aluminium alloy was assumed to be 30 minutes while for high alloy steel -60 minutes. The assuming of the longer development time than maximum one -30 minutes acc. to the PN-EN ISO 3452-1 - resulted from the suggestion presented in the literature [5] where the recommended development time for high alloy steel is at least 60 minutes. The indications were measured in the following time points: 2, 5, 10, 15, 20, 25 and 30 minutes as well as 35, 40, 45, 50, 55 and 60 minutes. Measurements carried out in the initial stage of the indications appearance were aimed at the determination of the dynamics of their formation as well as at the more precise determination of the relationship being the subject of this investigation. The view of specimens with developed indications is shown in the Fig. 4 as an example.

The results of penetrant testing of specimens with simulated pores are shown graphically in the Figs 5-7.

\section{Analysis of test results}

As it can be seen from Figs. 5-7, the coordinates of individual measurement points are determined by the measured size of the indication and by the controlled time of its development. The points having different coordinates but relating to the surface pore of the same size (i.e. pore of the same diameter and depth - nomenclature acc. to the EN ISO 6520-1) are connected by line segments forming thereby the broken line showing the relationship run which has been the goal of this investigation.

From the analysis of the broken lines run it results that, in every case, the maximum size of the imperfection indication increases together with the increase of the pore diameter. It is the result conformable to expectations. It should be noticed, however, that the course of the individual lines shows certain tendencies. In the initial stage of arising of the indications (development time being from 0 to 5 minutes) the broken lines are characterized by a considerable inclination to the axis of development time. It proves great dynamics of the indications increase and relates to the majority of observed cases.

In case of specimens made of unalloyed structural steel, within the range of development time of 5 to 30 minutes, the broken lines displaying the indications of small depth pores ( $h=0,5-1,0 \mathrm{~mm}$ ) quickly become parallel or almost parallel to the axis of development time. It means easy stabilization the maximum size of the indication. In case of larger size pores ( $h=1,25-1,75 \mathrm{~mm}$ and $\varnothing=1,25-1,75 \mathrm{~mm}$ ) the situation is different. In these cases stabilization of maximum indication size occurs in the later stage of the development process or does not occur at all (for example, the broken lines shown in the Figs. 5e and $5 \mathrm{f}$ show the raising tendency even after maximum development time). So, it is observed lack of stabilization of indications being measured. Hence, it results the conclusion that during colour penetrant testing of unalloyed structural steels the development time for indications coming from surface imperfections should be longer than that specified in EN ISO 3452-1.

In case of aluminium alloy specimens, it is also observed great dynamics of the indications increase in almost all events. 


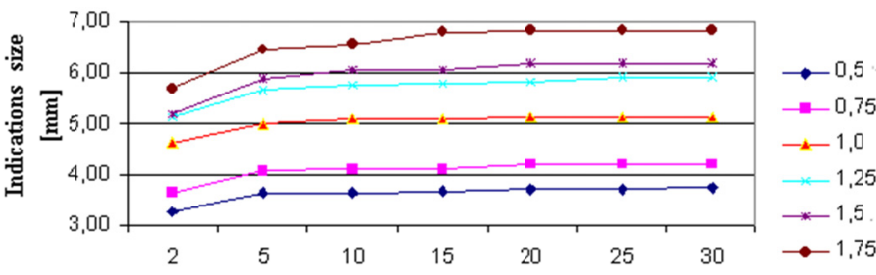

a)

Development time [min]

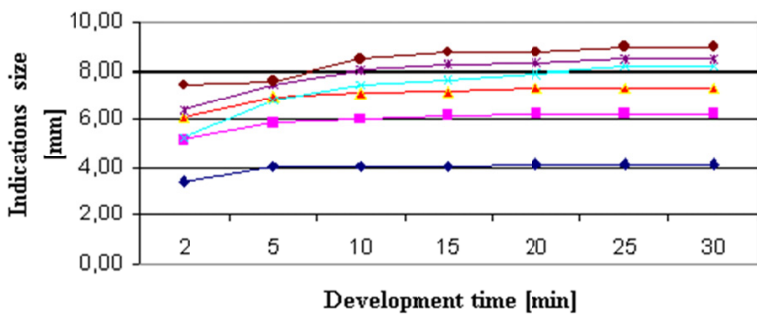

b)

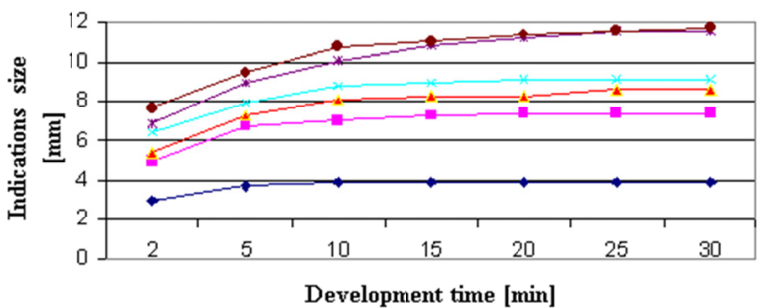

c)

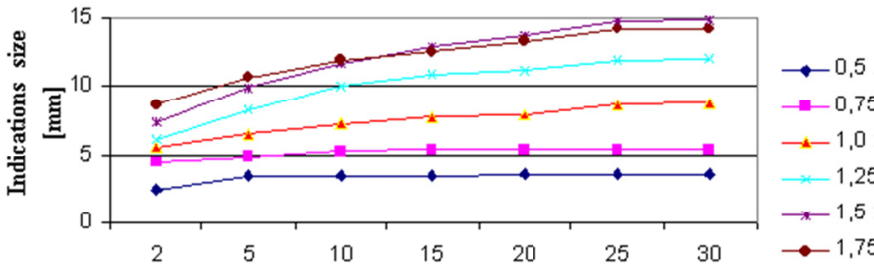

d)

Development time [min]
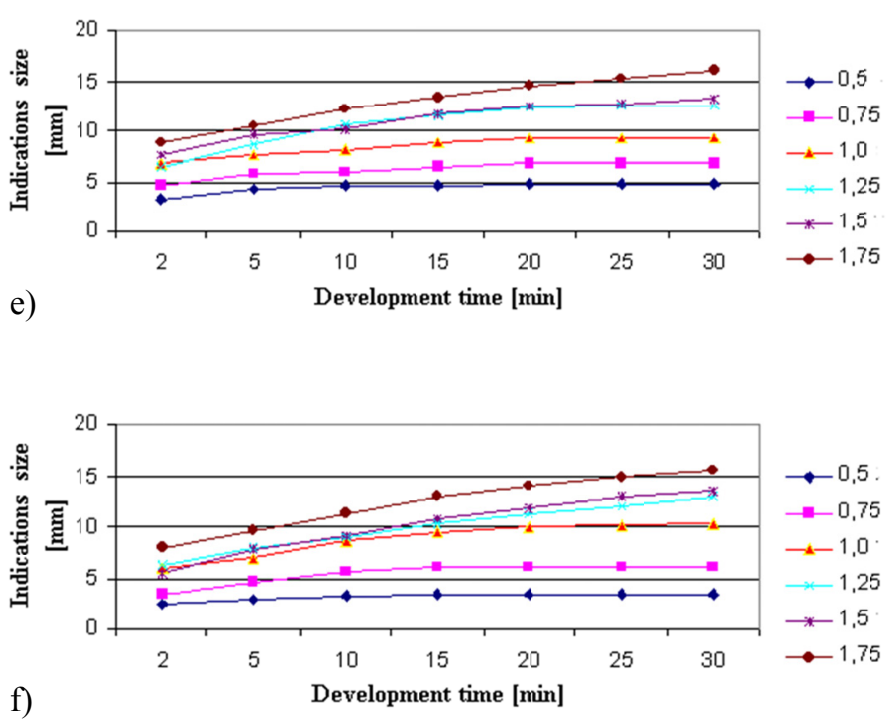

Fig. 5. Results of penetrant testing of specimens made of S235 carbon construction steel with different diameter holes, the nominal depth of which was as follows: a) $h=0,50 \mathrm{~mm}, \mathrm{~b}) h=0,75 \mathrm{~mm}, \mathrm{c}) h=1,00 \mathrm{~mm}$, d) $h=1,25 \mathrm{~mm}$, e) $h=1,50 \mathrm{~mm}$, f) $h=1,75 \mathrm{~mm}$
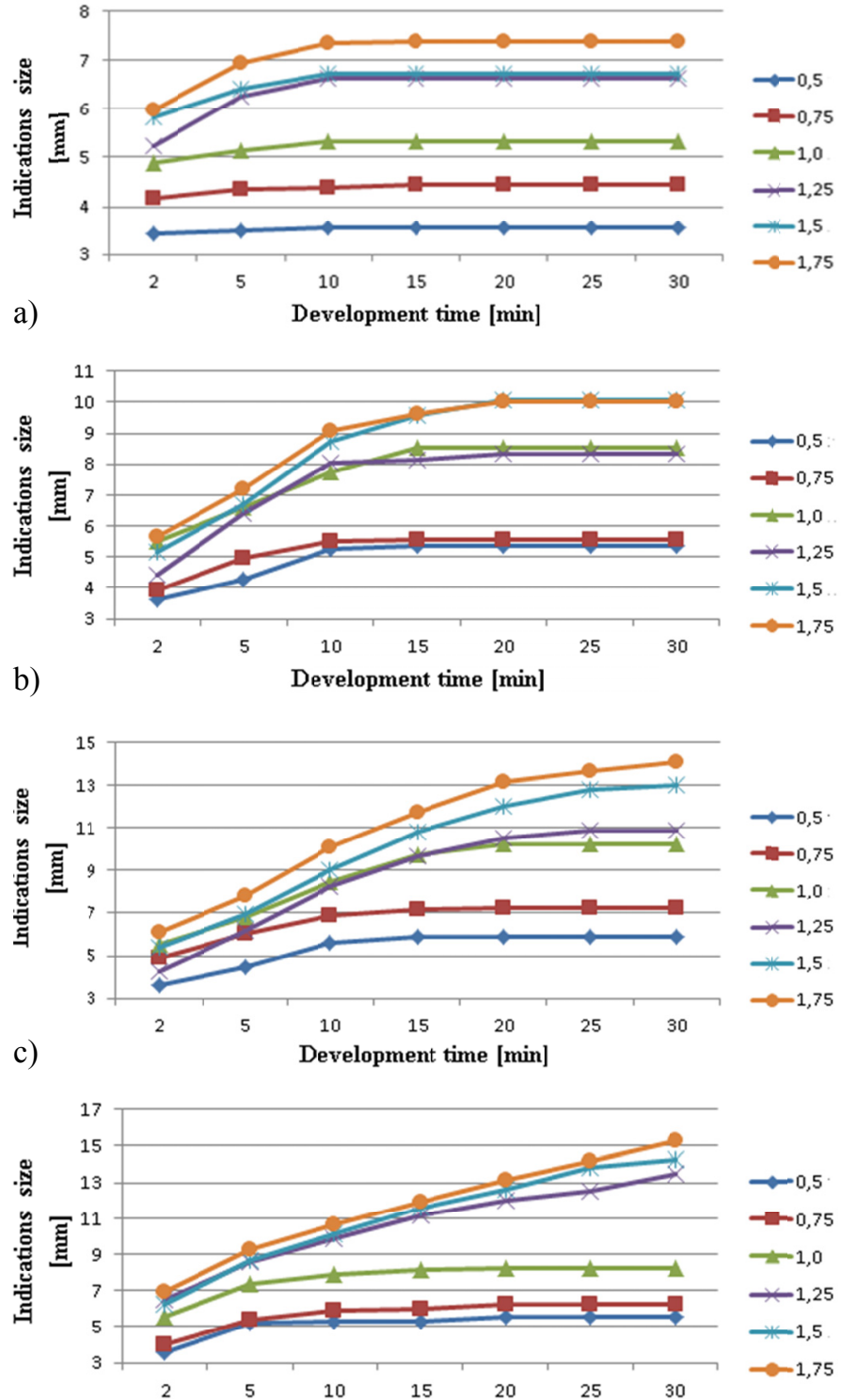

d)

Development time [min]
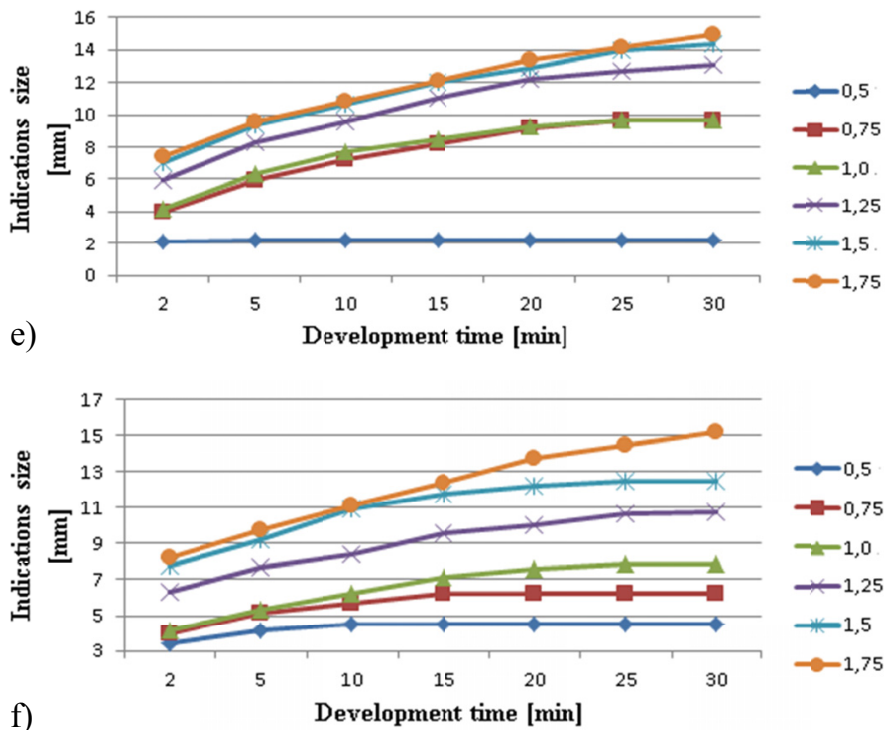

Fig. 6. Results of penetrant testing of specimens made of AlMg5 aluminium alloy with different diameter holes, the nominal depth of which was as follows: a) $h=0,50 \mathrm{~mm}$, b) $h=0,75 \mathrm{~mm}$, c) $h=1,00 \mathrm{~mm}$, d) $h=1,25 \mathrm{~mm}$, e) $h=1,50 \mathrm{~mm}$, f) $h=1,75 \mathrm{~mm}$ 

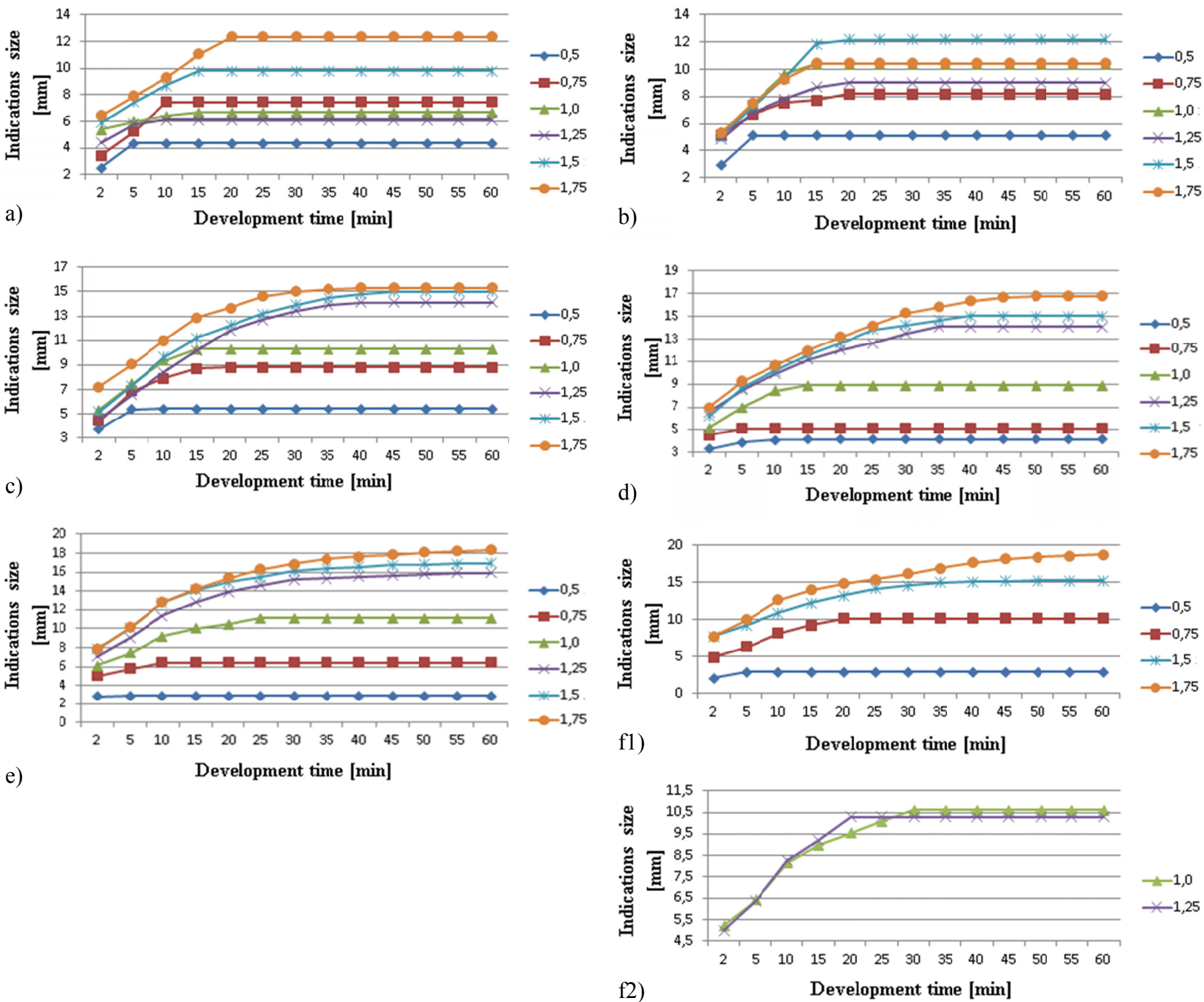

Fig. 7. Results of penetrant testing of specimens made of X5CrNi18-10 high alloy steel with different diameter holes, the nominal depth of which was as follows: a) $h=0,50 \mathrm{~mm}, \mathrm{~b}) h=0,75 \mathrm{~mm}$, c) $h=1,00 \mathrm{~mm}$, d) $h=1,25 \mathrm{~mm}$, e) $h=1,50 \mathrm{~mm}$, f1, f2) $h=1,75 \mathrm{~mm}$.

Note: in the Figs. f, the lines overlap each other and for that reason the broken lines for indications coming from holes $\varnothing 1,0 \times 1,75 \mathrm{~mm}$ and $\varnothing 1,25 \times 1,75 \mathrm{~mm}$ are shown in the separate diagram.

The lines representing the smallest pores $(h=0,5 \mathrm{~mm}$ and $\varnothing=0,5-1,0 \mathrm{~mm}$ ) (Fig. 6a), where the dynamics is inconsiderable, are an exception. Within the range of development time from 5 to 10 minutes, the dynamics of the indications increase usually becomes smaller. In majority of cases, however, the lines are characterized by considerable stabilization of indications after development time of about 15-20 minutes. Only the indications deriving from the largest simulated pores $(\varnothing=1,25-1,75 \mathrm{~mm}$ and $h=1,0-1,75 \mathrm{~mm}$ ) (Figs. 6c-6f) show the stabilizing tendency after the standard development time, i.e. about 30 minutes or keep the increasing tendency. It concerns, however, large pores sent usually to the repair without analyzing the admissibility of such a structure to the use. From the above presented consideration the conclusion results that during colour penetrant testing of aluminium and its alloys the development time for indications (coming from pores and most probably also from the other sur- face imperfections) can be shortened to about 15-20 minutes. When the number of tests is large, this can result in significant economical effect caused by saving of operation time.

Similarly to the earlier cases, in the specimens made of high alloy steel it was observed great dynamics of the increase of penetrant indications in the initial stage of their formation. The line representing the hole, $0,5 \mathrm{~mm}$ in dia. and $1,5 \mathrm{~mm}$ in depth, is an exception. The dynamics of the indications increase is here almost unnoticeable. Distinct, but smaller in comparison to the other lines, dynamics is displayed also by the lines representing the holes, $0,5-0,75 \mathrm{~mm}$ in dia. and $1,25 \mathrm{~mm}$ in depth. As it is observed, small dynamics of the penetrant indications increase is characteristic for the holes simulating pores small in the diameter and relatively large in the depth. In general, in the specimens of high alloy steel, the dynamics of the penetrant indications increase becomes smaller or stabilized within the range of the 
development time from about 10 to about 20 minutes. However, in many cases this time is at least 30-40 minutes. It results from the above, that extension of the standard development time up to about 45 minutes, during penetrant testing of high alloy steel, is reasonable.

It can be noticed that in all cases of structural materials testing (for example Figs. 5b, 5d-5f, 6b-6d, 7a, 7c) some broken lines "intersect". Such a fact is observed usually within the development time from 2 to 15 minutes. Sometimes, the lines representing pores smaller in the diameter show the maximum indications size larger than those representing pores bigger in diameter (for instance Figs. 5d, 6b). It is contradictory to the expectations. However, it should be taken into account the fact that the penetrant testing process includes the series of stages which have to be carried out. Each of the stages, considering the sensitivity of testing, must be carried out with attention to details, because any carelessness in the process run lowers sensitivity of testing, affecting the final result. Considering the above, it is easy to explain the inaccuracy in the course of some broken lines shown in the figures.

On the basis of relationships between the dimensions of indications and the time of their development vs. the imperfec- tion size it is possible to evaluate the pores depth. The general procedure in this scope comprises the following:

- measurement of pore diameter by means of slide caliper, weld gauge or by another equivalent way;

- making the penetrant testing in accordance with the EN ISO 3452-1 specifications;

- assurance the observation conditions in accordance with the EN ISO 3059 specifications;

- measurement of maximum dimensions of the indication after the passage of assumed development time;

- determination of the point with coordinates: indication size-development time in such a way that it is placed on the broken line corresponding the measured pore diameter or as close it as possible;

- reading the estimated pore depth determining the broken line fixed earlier.

The example of the manner of determination of the assessed pore depth is shown in Fig. 8 with application of selected, for clarity, broken lines (specimens of S235 steel).

Then, it can be concluded that the depth of the pore, $1,2 \mathrm{~mm}$ in diameter, is about $1,2 \mathrm{~mm}$.

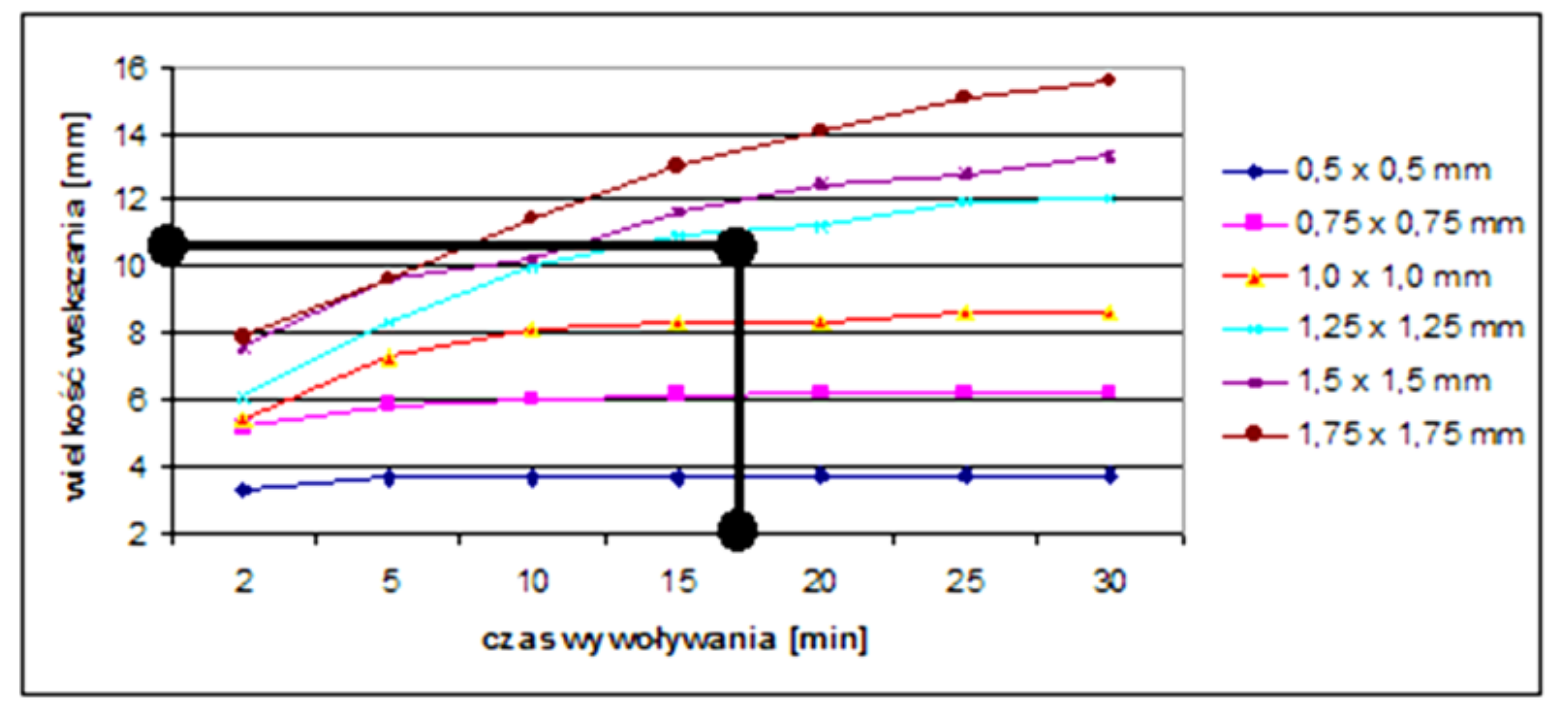

Fig. 8. Example of determination of the assessed pore depth on specimens of unalloyed structural steels. The measured data: pore diameter $-1,25 \mathrm{~mm}$, indication size $-10,5 \mathrm{~mm}$, development time - 17 minutes. As it can be seen, the point of intersection of coordinates: 10,5 mm and 17 minutes lies somewhat below the broken line representing the pore, $1,25 \mathrm{~mm}$ in diameter and 1,25 $\mathrm{mm}$ in depth

\section{Summary and conclusions}

The penetrant testing carried out on the specimens with holes simulating pores has proved that the aim of the investigation has been achieved. The relationships determined by the authors (indications size-development time vs. imperfection dimensions) enable to evaluate the pores depth in elements made of unalloyed structural steels, aluminium and its alloys as well as of high alloy steels. Information about this subject should make easier to take decision about admittance the product to the operation or about its repair. It may be well to notice that in some events, after the maximum development time, it was observed lack of stabilization of the penetrant indications under measurement. It suggests that this time should be longer than that recommended in the EN ISO 3452-1 standard. Moreover, on the basis of the evaluated pore depth it can be concluded about the possible leakage of welded joints, especially those with fillet welds. In relation to some products ( for instance storage vessels) it can be of essential importance. On the grounds of the investigations and the analysis of their results the following conclusions can be formulated:

- the testing carried out by colour penetrant technique allowed to achieve the aim of the work, it means the obtainment of the possibility of evaluation of the pores depth in products 
made of unalloyed structural steels, aluminium and its alloys as well as of high alloy steels;

- maximum development time for indications on surfaces of unalloyed structural steels should be longer than that specified in EN ISO 3452-1;

- maximum development time for indications on surfaces of aluminium and its alloys may be reduced to about $15-20$ minutes;

- maximum development time for indications on surfaces of high alloy steels should be extended to at least about 45 minutes;

- the tests enable to assess the leak tightness of welded joints, specially those with fillet welds.

\section{REFERENCES}

[1] T. Robakowski. Wpływ wad w złączach spawanych na własności eksploatacyjne konstrukcji spawanych. (The influence of welding defects on operational properties of welded structures). Wydawnictwo Instytutu Spawalnictwa. Gliwice 1997.

[2] K. Ciechacki, T. Giętka. Badanie spoin - badania nieniszczące. (Examination of welds - non-destructive testing). Wydawnictwo Naukowe Instytutu Technologii Eksploatacji - Państwowego Instytutu Badawczego. Radom, 2015.

[3] A. Klimpel, A. Szymański. Kontrola jakości w spawalnictwie. (Quality control in welding). Wydawnictwo Politechniki Śląskiej. Gliwice, 1992.

[4] A. Lewińska-Romicka. Badania nieniszczące: podstawy defektoskopii. (Non-destructive testing: base flaw). Wydawnictwo Naukowo-Techniczne. Warszawa 2001.

[5] R. Ostrowski. Defektoskopia penetracyjna. (Penetrant inspection). Wydawnictwo Instytutu Metalurgii Żelaza oraz Resortowego Ośrodka Doskonalenia Kadr. Gliwice - Chorzów 1983.

[6] A. Borowiecka. Badania penetracyjne. Poradnik. (Penetrant testing. Guide). Wydawnictwo „Biuro Gamma”. Warszawa 2000.

[7] W. Wojciechowski, T. Stefaniec, M. Wątroba. Badania nieniszczące w spawalnictwie. ( Non-destructive testing in welding). Politechnika Krakowska im. Tadeusza Kościuszki: Centrum Szkolenia i Organizacji Systemów Jakości. Kraków, 2005.

[8] J. Czuchryj, K. Hyc. Ocena wielkości nieciagłości powierzchniowych w wyrobach z węglowej stali konstrukcyjnej na podstawie badań penetracyjnych metodą barwną. (Assessment of the surface discontinuities size in carbon constructional steel products on the grounds of colour liquid-penetrant inspection). Biuletyn Instytutu Spawalnictwa 4 (2012).
[9] J. Czuchryj, P. Irek. Ocena wielkości porów na podstawie badań penetracyjnych metodą barwną w złączach spawanych $\mathrm{z}$ aluminium i jego stopów.(Evaluation of pore size on the grounds of colour liquid-penetrant inspection in welded joints of aluminium and its alloys). Biuletyn Instytutu Spawalnictwa 4, (2014).

[10] J. Czuchryj, P. Irek. Ocena wielkości porów na podstawie badań penetracyjnych metodą barwną w złączach spawanych ze stali wysokostopowej. (Evaluation of pore size on the grounds of colour liquid-penetrant inspection in welded joints of high alloy steel). Biuletyn Instytutu Spawalnictwa 1 (2015)

[11] A. Lisiecki, Welding of titanium alloy by Disk laser. Proceedings of SPIE, Laser Technology, Applications of Lasers, 87030 (2013).

[12] B. Ślązak, J. Słania, T. Węgrzyn, et al., Process stability evaluation of manual metal arc welding using digital signals. Materials Science Forum 730-732, 847-852, (2011).

\section{List of applied standards:}

- $\quad$ EN ISO 3452-1: Badania nieniszczące. Badania penetracyjne. Część 1: Zasady ogólne (Non-destructive testing - Penetrant testing - Part 1: General principles).

- $\quad$ EN ISO 3452-2: Badania nieniszczące. Badania penetracyjne. Część 2: Badania materiałów penetracyjnych (Non-destructive testing-Penetrant testing - Part 2: Testing of penetrant materials).

- $\quad$ EN ISO 3452-3: Badania nieniszczące. Badania penetracyjne. Część 3: Próbki odniesienia (Non-destructive testing - Penetrant testing - Part 3: Reference test blocks).

- $\quad$ EN ISO 3452-4: Badania nieniszczące. Badania penetracyjne. Część 4: Wyposażenie (Non-destructive testing - Penetrant testing - Part 4: Equipment).

- ISO 3058: Badania nieniszczące. Przyrządy pomocnicze do badań wizualnych. Dobór lup o małych powiększeniach (Non-destructive testing - Aids to visual inspection - Selection of low-power magnifiers).

- EN ISO 3059: Badania nieniszczące. Badania penetracyjne i badania magnetyczno-proszkowe. Warunki obserwacji (Nondestructive testing - Penetrant testing and magnetic particle testing - Viewing conditions).

- $\quad$ EN ISO 12706: Badania nieniszczące. Terminologia. Terminy stosowane w badaniach penetracyjnych (Non-destructive testing - Penetrant testing - Vocabulary).

- EN ISO 6520-1: Spawanie i procesy pokrewne. Klasyfikacja geometrycznych niezgodności spawalniczych w metalach. Część 1: Spawanie (Welding and allied processes - Classification of geometric imperfections in metallic materials - Part 1: Fusion welding). 